\title{
The Price Behavior around Initial Loan Announcements: Evidence from Zero-leverage Firms in the UK
}

\begin{abstract}
This paper analyses price effects of trades around the initial loan announcements for 96 zeroleverage firms listed on the FTSE 350 index over the time of period 2000 to 2015. Using a very large sample size of 28 million share purchases and 26 million share sales, we discover price continuations follow buys and reversals follow sales. We also observe that purchases have a greater impact on permanent price changes. Once price effects are estimated using quote returns to eliminate the bid-ask bias, the asymmetry in buyer and seller initiated trades is dramatically reduced. Our results suggest that the bid-ask bounce can explain asymmetry in the trading direction of zero-leverage firms when they encounter debt for the first time.
\end{abstract}

JEL classification: G12, G14, G15

Key words: Zero-leverage firms; price impact; bid-ask bounce; liquidity. 


\section{Introduction}

Over the last two decades, the price impact of trades has been an extensively research area in both empirical and theoretical finance. Extant literatures analyze the asymmetry in the price of buyer-and seller-initiated trades on financial markets all over the world. Such as the London Stock Exchange (Gemmill, 1996), the Australian equity market (Aitken and Frino, 1996), and the U.S. market (Chiyachantana et al., 2017). Aitken and Frino (1996), consistent with many previous researchers, establish that the sellers pay a liquidity premium while buyers do not, as price reversals are usually associated with sales while price continuations follow purchases.

One of the common explanations (e.g.: Kraus and Stoll, 1972; Chan and Lakonishok, 1993; Keim and Madhavan, 1996) is that sellers and buyers respond to information differently, buyerinitiated are usually found to be better informed than seller-initiated trades, leading to buy orders having a greater permanent price impact than sells. Chiyachantana et al. (2017) indicates that the permanent asymmetric price impact between buys and sells is positive at the initial stage of price run-up, which then reverses in the prolonged price increasing period. These results are all based on the behavior of block trades, which are defined as an order submitted with a minimum trade size of 10,000 shares (Madhavan and Cheng, 1997; Gregoriou, 2008). Block trades have a higher level of monitoring, and the block traders usually have a larger market capitalization and higher level of liquidity. In contrast with small or median trades, the empirical results may be different. This point is illustrated in Brennan et al. (2012), when they discover for all NYSE stocks that seller-initiated orders are priced higher in the cross-section of equity returns.

Given that the vast majority of the previous literature is based on block trades, our objective is to focus on the price impact effect on all trades concerning zero-leverage firms around their 
initial loan announcement. This is an important corporate event that has been neglected in the finance literature thus far. Our research to our knowledge, is the first to examine the asymmetric price impact of zero-leverage firms around their initial loan announcement. A zero-leverage firm is defined as a company that does not possess any short or long-term debt. Frino et al. (2017) suggest that the magnitude of price impact depends on both the information content of a trade and how market makers respond to this information. Given the level of asymmetric information changes around the initial loan announcement of zero leverage firms, we believe that it is very important to examine how the market responds to these substantial information fluctuations. We would expect that the asymmetric price effect and the bid-ask bias should be larger for our sample than for levered firms listed in widely established financial markets such as the FTSE 100 or the NASDAQ. For completeness we also examine the difference between zero-leverage and levered firms. We do this by computing the price impact of all levered firms in our sample, when zero leverage firms obtain debt for the first time.

Our second contribution is that we scrutinize the bid-ask bounce of zero-leverage firms around the initial loan announcement. We believe that the asymmetric buy and sell impact during the announcement period of zero-leverage firms could be explained by the bid-ask bounce. The bid-ask bounce refers to the bouncing of trading prices between the bid and ask sides of the markets which would be the case if the order flow was imbalanced. As trades move out from the mid-point between the bid and ask price this results in a spurious gain or loss which is later reversed as transactions resume back to the mid-point (Gosnell et al., 1996). Han and Lesmond (2011) reveal that the bid-ask bounce effect is more important for the pricing of small and illiquid stocks. Kaul and Nimalendran (1990) show that in their sample from the NASDAQ between 1983 to 1987, bid-ask errors can explain about 50\% of the daily return variances of small firms, whereas for the largest firms in their sample this proportion is just 23\%. Therefore, for zero-leverage firms which are renowned for being less liquid than levered firms (see among 
others, Faulkender and Petersen, 2005 and Hadlock and Pierce, 2010), we have the objective to explore their price impact and order flow imbalance.

Some studies (see among others, Frino and Oetomo, 2005 and Berkman et al., 2005) fail to find the asymmetric price impact of buy and sell trades. This could be because their results are based on future markets, which have less private information, and thus lower information asymmetry. In contrast, for zero-leverage firms, the magnitude of price impact should be larger than levered firms. Furthermore, Saar (2001) indicate that the history of past price performance influences the degree of the asymmetry between purchases and sales.

One of the other contributions of our study is the size of our sample. We investigate the price impact of zero-leverage firms traded on the London Stock Exchange over a 16-year time period. Our data span is significantly longer than previous studies, for instance, Alzahrani et al. (2013) looks at 4 years and Gregoriou (2008) explores 8 years of time series data. Moreover, our observations are significantly larger than previous studies. This is because our sample is based on all trades and industries. We examine 28,342,080 buy and 26,101,600 sell trades in our empirical framework, which is approximately six times higher than Alzahrani et al. (2013) and 20 times larger than Gregoriou (2008).

The remainder of the paper is organized in the following way. In the next Section we provide a review of the previous literature. Section 3 discusses the data. Section 4 describes the econometric methodology used to undertake our study. The empirical analysis is reported in Section 5 and finally Section 6 concludes. 


\section{Literature review}

The zero-leverage capital structure policy is becoming increasingly popular over time. Strebulaev and Yang (2013) find from 1962 to 2009, 10.2\% of large public firms follow zeroleverage policy in the U.S, and that almost $22 \%$ firms have less than a $5 \%$ book leverage ratio. Dang (2013) discovers in his UK sample, more than $12.8 \%$ of firms operate a zero-leverage policy between 1980 and 2007. Hadlock and Pierce (2010), consistent with Faulkender and Petersen (2005), report that the zero-leverage firm which has shorter history and smaller size suffer more from information asymmetry problems, very little public information is available about such firms, and given their small size, the relative cost of collecting information can be quite high, therefore they are more likely to borrow from financial intermediaries.

Datta et al. (1999) believes that banks are able to examine potential borrowers more effectively than the public as they have access to private information about the borrower, giving them a relative information advantage over external parties. Therefore, bank loan announcements are reliable signals of firms' quality and potential performance. Chiyachantana et al. (2017) shows that at the initial stages of price run-up, the asymmetry is generally positive, for stocks with a higher degree of information asymmetry such as zero-leverage firms, price impact asymmetry is more pronounced. Zero-leverage firms are subject to greater asymmetric information resulting in higher bid-ask spread costs, which could lead to significant changes in asymmetric price impact during the announcement period.

Chan and Lakonishok (1993) among others suggest that the purchases are based on the arrival of new firm-specific information such as the initial loan announcement, whereas sales are motivated by liquidity requirements. According to Kraus and Stoll (1972) and Chiyachanta na et al. (2017), the total price impact is composed of temporary and permanent price impact, 
temporary price impact which relates to liquidity effects or changed bid-ask spread from a temporary imbalance in demand and supply, and permanent price impact, which relates to any new information permanently impounded into the stock price, leading to the price changes contribute to a new equilibrium level at the market. We expect that after the announcement of the initial loan new information into prices through the new loan announcements may impact on the price impact asymmetry.

The size of the spread is the other source of the errors in the transaction price. In fact, the bidask bounce error can be unnoticeable if the size of the spread is minimal. Han and Lesmond (2011) reveal that the size of the bid-ask spread directly affects the estimated volatility through inflation in the daily return.

Previous studies emphasize that the bid-ask bounce is one of the source of price reversals, Blume and Stambaugh (1983) demonstrate that daily returns are biased due to the bid-ask bounce, suggesting that the reversals might simply be a shift from transactions at bid prices to transactions at ask prices. Roll (1984) indicates that the stock returns will be negatively correlated due to transaction prices bouncing between bid and ask prices. Han and Lesmond (2011) argue that the bid-ask bounce inherent a liquidity bias, the price movement is not a "true" price movement, but that it nevertheless increases the volatility of stock returns and consequently price reversal. Lease et al. (1991) also finds that the bid-ask bounce explains negative returns on the seasoned equity offerings date, while Cox and Peterson (1994) find that it explains short-term price reversals following large one-day price declines.

Levi and Zhang (2015) establish that stock sales drive the information asymmetry because investors requiring liquidity sell stock at discounted prices relative to the pre announcement 
time period.

However, Lee (1992) examines the reaction of imbalance trade direction which causes the asymmetric price impact to different types of earnings news, and finds that the order imbala nce before "good" or "bad" news is indistinguishable from any other time, regardless of the trading volume.

\section{Data}

\subsection{Firm data}

We collect data from all the zero-leverage firms listed on the FTSE 350 index actively traded from the start of January 2000 to the end of December 2015. The FTSE 350 index is defined as the aggregation of the FTSE 100 and FTSE 250 indices, which consists of the 350 largest firms listed on the London Stock Exchange with respect to market capitalization. The FTSE 350 represents around $89 \%$ of the entire trading volume on the London Stock Exchange ${ }^{1}$, enabling us to obtain a very accurate description of the UK stock market. Our data sample consists of zero-leverage firms that have encountered debt for the first time during our sample period. We also collect data on all levered firms listed on the FTSE 350, around the same time period for comparison purposes.

We amass all FTSE 350 firm data from Thomas Reuter Eikon, a worldscope fundamental financial database. For each company we obtain the trade and closing price, bid price and ask price, both daily and intraday ${ }^{2}$. We also collect information concerning the initial loan

\footnotetext{
${ }^{1}$ According to the secondary market fact sheet issued by the London Stock Exchange in September 2007.

${ }^{2}$ Brooks and Chiou (1995) report that the end of day bid-ask price might be bias. In our study, the end of day and intraday spread are highly correlated with each other. The spearman's rank correlation coefficients between the closing day absolute (relative) spread and intraday absolute (relative) spreads in our sample period are approximately $0.83(0.81)$.
} 
undertaken by the firm including the issue date and the loan amount. In total, there are 96 zeroleverage firms and 195 levered firms within FTSE 350 over our sample period, that have sufficient data for econometric analysis.

The descriptive statistics are presented in Table 1. Panel A compares zero-leverage and all FTSE 350 firms. Our findings agree with Faulkender and Petersen (2005), who state that zeroleverage firms are smaller than their levered counterpart firms. This is reflected by the average market capitalization of approximately £3995 million for zero leverage firms as compared to $£ 4231$ million for all FTSE 350 firms. This result is in direct contrast to Strebulaev and Yang (2013), who believe that the existence of zero-debt policy is independent of firm size. A possible reason for the difference in our findings could be because they compare zero-leverage to almost zero leverage firms, which are similar in both debt capacity and market capitalization. Furthermore, all three spread measures of zero-leverage firms are larger than all FTSE 350 firms. This implies that zero-leverage firms are less liquid then all FTSE 350 firms regardless of the measure of liquidity. This is consistent with prior research stating that zero-leverage firms lack information due to their non-exposure to debt financing.

Turning our attention to the standard deviation of returns, for the two groups there is no significant difference (1.250 for zero-debt firms and 1.231 for all firms). Panel B reports the descriptive statistics on loan amounts. The amount of the initial loan is on average around $£ 1537.29$ million, with a median value of 248.92 million. The loan amounts are extremely variable reflected by the excess skewness of the data, with a range of approximately $£ 69049$ million. 


\subsection{Trading data}

Following Lee and Ready (1991), we construct buy and sell indicator variables in the following way. If the stock price is higher than the mid-quote, the trade is considered "buyer-initiated"'. If the stock price is lower than the mid-price, then it is considered "seller-initiated". Hasbrouck and Ho (1987) state that the basic bid-ask model relies on the assumption that buyers and sellers arrive independently and with equal probability. Hence, a transaction at the bid price is equally likely to be followed by a transaction at the bid or ask price. Panel $\mathrm{C}$ of Table 1 presents the trades analyzed in our research. The overall sample consists of 28,342,080 purchases and 26,101,600 sales, which is substantially larger when compared with previous research. For instance, Madhavan and Cheng (1997) only examine 21077 block trades while Chan and Lakonishok (1993) analyze 1,215,387 transactions. Alzahrani et al. (2013) contains around $4,200,000$ trades in their research with $2,300,000$ of buy orders and 1,800,000 sell orders.

The mean and median trade sizes were 9978 and 6630 respectively for purchases, and 9484 and 6508 respectively for sales. For the standard deviation of our samples, stock purchases have a standard deviation of 41256.8 whereas the stock sell standard deviation is 44523.0. They are significantly larger than the research of Gregoriou (2008) which focuses on block trades. This is due to the fact that we focus upon all trades regardless of size, which results in more data and hence greater volatility. More importantly, it indicates that the zero-leverage firms are riskier than block trades. The firms undertaking block transactions usually have large market capitalization and less asymmetric information between insiders and outsiders, whereas zeroleverage firms usually have smaller market capitalization, more asymmetric information causing greater risk on their stocks. Moreover, the standard deviation of buyer-initiated orders is larger than the seller-initiated, indicate the buy order is more volatility than sells. 


\section{Methodology}

\subsection{Price Impact}

Kraus and Stoll (1972), consistent with Scholes (1972), suggest that the temporary and permanent price effects can be explained by different theories. In particular, liquidity costs and price pressure theories are used to explain temporary trade price effects, while for permanent price effects the substitution effect and the release of new information are given as potential descriptions. Anderson et al. (2006) reports temporary price effect following sells because prices typically rebound back to the previous levels. In contrast, prices remain significantly higher following purchases. To cover a broad spectrum of the price effect on the zero-leverage firms, we also construct price effects on all FTSE 350 index firms that possess debt financing.

Following previous literature (see among others Madhavan and Cheng, 1997) trade price effects are measured as follows:

$$
\begin{gathered}
\text { Temporary Effect }=\log \frac{P_{a}}{P_{c}} \\
\text { Permanent Effect }=\log \frac{P_{c}}{\mathrm{P}_{p}} \\
\text { Total Effect }=\log \frac{P_{a}}{\mathrm{P}_{p}}
\end{gathered}
$$

Where $P_{p}$ denotes the market price prior to the initial loan announcement for zero-leverage firms, while $P_{c}$ represents the price after the initial loan announcement for zero-leverage firms. $P_{a}$ conveys the trading price of zero leverage firms around the announcement time. Given data limitations, it is not possible to do one-to-one correspondence between announcement time and trades executed on the announcement moment. We use the closing price of one day before the announcement day, the closing price on the announcement day and the average trading price around the announcement time. For all other leverage firms, similar with the zero-leverage 
firms, we construct the same event day with the initial loan announcement and all variables in equations (1) to (3) are defined in the same way ${ }^{3}$.

\subsection{Order flow ratio}

For exploring whether the asymmetry between purchases and sells is attributable to the tendency to trade at the ask price, we test the bid-ask bounce by determining the location of trade prices used to calculate trade price effects. Using the trade classification of Lee and Ready $(1991)^{4}$, the location of trade prices can be classified as: A. Above and at the ask price. B. Between the ask and midpoint price. C. Between the midpoint price and the bid price. D. At and below the bid price. The frequency of trades at the bid and the ask price are computed using the order flow ratio, which is calculated for the open and closing price on the initial loan announcement days, as follows:

$$
\text { Order flow ratio }=\frac{(\text { ask }- \text { price })}{(\text { ask-bid })}
$$

Where ask equals the ask price of zero-leverage firms, Price signifies the transaction price of zero-leverage firms and Bid represents the bid price of zero-leverage firms. The closer the order flow ratio is to 1 , the more likely the transaction price is at the bid quote, indicating the selling pressure. While the closer this ratio is to zero the greater the likelihood the trade is at the ask, an indication of buying pressure (Lease et al.,1991). Buyers are assumed to purchase at ask price whereas sellers trades as bid price.

\footnotetext{
3 Frino et al. (2008) examine the closing and execution price fifteen minutes before and after the trade. Their results are similar to using the opening and closing prices as benchmarks.

${ }^{4}$ Odders-White (2000) and Theissen,(2001) show that the Lee and Ready (1991) classification is biased towards buy trades. Eventhough we accept the drawbacks of the Lee and Ready (1991) technique, we believe it is less of an issue for the London Stock Exchange. This is because their Electronic Trading System (SETS), eliminates a vast proportion of the systematic pattern problem (Gregoriou, 2015). This increases the accuracy of the Lee and Ready (1991) classification.
} 


\section{Empirical results}

\subsection{Transaction price effects of zero-leverage trades.}

Table 2 summarizes the intraday price impact of purchases and sales for zero-leverage firms based on the closing price, and the same day price impact of all other levered FTSE 350 index firms. The tests of equality report the mean difference in the net effects between buyer-initialled and seller-initialled orders. A positive value indicates that the net effect of buys is larger than that of sales. A negative difference shows that the net effect of sales is greater than purchases. In Panel A we observe for zero leverage firms a significant asymmetry in the intraday price behavior of buyer and seller- initiated trades. Purchases are executed at prices 40.00 percent above the opening price, and show a clear continuation, which is subsequently subsumed into the permanent effect of 27.99 basis points. For seller-initiated trades, sales are associated with a continuation of 2.56 basis points in temporary price effects, which is not consistent with the reversal predicted by the short-run liquidity costs hypothesis. Permanent price effects suggest that sales move the stock price on average by -22.69 basis points, which is consistent with the information hypothesis established by Kraus and Stoll (1972). Sales exhibit a total effect of 33.07 basis points. Tests of equality for all three measured price impacts show that purchases have a significantly greater impact than sales, and the asymmetry is more pronounced in permanent and total effects. The results of Table 2 confirm that the level of asymmetric price impact depends on both the information content of the trade and on the reaction of market makers (Frino et al., 2017).

In contrast to the results of the zero-leverage firms, in Panel B of Table 2, the magnitude of price effects of levered FTSE 350 index firms are significantly reduced across all three price impact measures. For instance, the permanent impact of buy orders is 13.47 and for sales the impact is -7.82. Both these price effects are substantially smaller than the price impact of zero- 
leverage firms. Furthermore, the average purchases in the FTSE 350 index levered firms has 3.73 points greater impact than a corresponding sell in the market. This is considerable smaller than the differences between buy and sell orders for zero-leverage firms around the initial loan announcement (6.93). A possible reason is that the market reaction is significant when the zeroleverage firms announce their first loan. The announcement attracts more buy orders and the asymmetric price effect between buy and sell orders increases significantly.

\section{[INSERT TABLE 2 HERE]}

\subsection{Price Impacts of Trades Purged of Bid-ask Bias}

Our research thus far has shown that purchases exhibit a greater impact on stock price, and that the asymmetry is of greater magnitude for the zero leverage firms. Engle and Patton (2004) discover that the reason of asymmetric impact of buyer-or seller-initiated transactions on market quotes is purchases represent a greater impact on the ask price than on the bid price, while sells have a greater impact on the bid side of market. Therefore, in this section we examine the buyer-initiated trades using ask price and seller-initiated trade price effects using bid prices. We incorporate this by replacing the transaction price, $P_{c}$ in equations (1) and (2), $P_{p}$ in equation (2) and (3) with the bid/ask quote price, while maintaining $P_{a}$ as the trading price for both firm $i$ and firm $j$. Mean and median returns purged of bid-ask bias displayed in Table 3 give a different impression of a trade around the initial loan announcement of zero-leverage firms.

First, for zero-leverage firms, Panel A of table 3 represents the intraday ask-trade-ask returns, purchases are associated with a significant permanent price of 20.49 basis point, and a total effect of 33.76 basis points. In terms of seller-initiated trades, reversals following sales moved the price at -3.26 basis points in the temporary effect predicted by short run liquidity costs, and 
in the total impact of -30.28 basic points. The results of test of equality suggest that even though purchases remain significantly different to sales, there is a reduction in the magnitude of the asymmetry relative to the results of Table 2. For example, after we purged the bid-ask bias, the temporary price impact asymmetry between buys and sells decrease from 2.28 to 1.88 , which is significantly different at the $1 \%$ level. For permanent impact and total impact, the reduction in asymmetry is more pronounced, from 5.3 to 4.10 , and 6.93 to 3.48 respectively. Therefore, bid-ask bias could be a possible explanation for the directional asymmetry in return between buyer-and seller-initiated trades.

For the levered firms in Panel B of Table 3, the magnitude of price impact also decreases after we eliminate the bid-ask bias by applying the quote price. For example, the permanent effect of buys decreases from 13.47 to 9.24 , and sales decline from -7.82 to -6.26 . However, the changes are not as dramatic as the zero-leverage firms. Comparing the results between two Panels of Table 3, for zero-leverage firms, the mean net permanent price impact of buys (20.49) and sales (-16.39) is greater in magnitude to all other levered firms buys (9.24) and sales (6.26). Econometric tests of differences between price effects are statistically significant at all conventional levels for the initial loan announcement day. Thus, it is clear that the magnitude of the total price impact of buys and sells are significantly larger than the corresponding total price impact documented for levered FTSE 350 index stocks.

\section{[INSERT TABLE 3 HERE]}

\subsection{Propensity to trade at the ask quotes order flow}

One approach to inferring whether a transaction is initiated by a buy or sell order is to measure the proximity of the daily closing transaction price to the closing bid and ask quotes. Table 4 presents the percentages of daily closing prices occurring at the ask, bid, and midpoint for both 
zero-leverage firms and levered firms on initial loan announcement day. For zero-leverage firms trading in Panel A, there is significant evidence that both the opening and closing prices have a propensity to be at the ask. On the initial loan announcement day, $17.61 \%$ of the opening prices are at the ask, while $13.94 \%$ are at the bid. For closing prices, the percentage is $29.45 \%$ and $26.50 \%$ respectively. Tests of equal proportions based on chi-square tests reveal a significant difference across categories. For all other levered firms in Panel B, during the same time period, $22.38 \%$ of the opening price are at the ask, while $20.07 \%$ are at the bid. The closing prices occurring at the ask are $26.50 \%$ and $19.28 \%$ appear at the bid.

In the last column of Panel A, we report the order flow ratio which in both open and closing prices is smaller than 0.5 and nearer to 0 . In particular, these are 0.453 and 0.468 respectively. The difference between open and closing price order flow ratio suggests a decrease in sell orders and an increase in buy orders on the day of the initial loan announcement. It is consistent with Chan and Lakonishok (1993) who believe that favorable firm-specific news is associated with more buy orders. For all other levered firms in Panel B, the order flow ratio is higher than zero-leverage firms. For opening and closing price the figures are 0.489 and 0.477 respectively, which are smaller than 0.5 . The results of Table 4 demonstrate that the order flow imbalance changes are more dramatic for the firms which have announced the initial loan. Entry into the credit market for the first time attracts more buy orders and causes a positive market reaction.

\section{[INSERT TABLE 4 HERE]}

\subsection{Bid-ask Bounce of Buy and Sell around the initial loan announcement of zero-leverage firms}

Following Alzahrani et al. (2013), we compare the daily spreads between buy orders and sell orders of both zero-leverage firms and all other FTSE 350 index firms in Table 5. The average quoted spread is defined as the ask price minus the bid price, whereas the average relative 
spread is expressed as the ask price minus the bid price, divided by the midpoint. Panel A represents the bid-ask bounce at 90 days before the announcement for two firm groups. First, for zero-leverage firms, we observe that the quoted spreads of buy orders (2.080) is larger than sell orders (2.076), with a difference of 0.004 . On the contrary, the average relative spread is slightly lower for purchases at 0.016 compared to 0.019 for sales, with a difference of 0.003 . All differences are small but are statistically significant. For all other firms, the quoted (relative) spreads of buy orders is $1.919(0.009)$ while sell orders is $1.924(0.011)$. These are all smaller than spreads for zero-leverage firms. The asymmetry between buy and sell orders are $-0.005(-0.002)$.

On the announcement days from Panel B, for zero-leverage firms, the daily quoted spread of buy orders, is 1.902 whereas the sell orders are 1.983 . The difference is 0.081 and is significantly different at the $10 \%$ level, which is much larger than the period before the announcement. It shows that the market liquidity reacts strongly when a bank sends a favorable signal through the announcement of the initial loan announcement. Turning to the daily relative spread, the difference between buy-orders and sell-orders is 0.005, and is statistically significant at the $10 \%$ level, which is larger than the difference in the pre-announcement period. Initial loan announcements can be regarded as favorable firm-specific news that attract more buyers from the market. The larger amount of buy orders causes the deviation, which is more pronounced on the announcement day. For the levered firms, the average quoted (relative) spreads of buy orders is $1.953(0.014)$ while for sell orders it is $1.956(0.015)$. The asymmetry between buy and sell order spread is $-0.003(-0.001)$. There is no difference between the preannouncement and event day period.

Finally, during the 90 days after the initial loan announcement, for zero-leverage firms, the daily quoted spread of buy order is 2.022 and 2.050 for sell orders, the difference is 0.028 , 
which is significant at $10 \%$ level. For relative spread the difference is small, 0.019 and 0.025 respectively. For all other levered firms, there are no significant changes in buy and sell orders. Overall, after the initial loan announcements, in our research, both quoted spread and relative spread of buy orders is smaller than sell orders. This asymmetry of buy and sell orders always exist in our sample regardless of the event announcements. Moreover, the asymmetry of zeroleverage firms is more significant than the levered firms. This is consistent with the notion that the initial loan announcement attracts more buy orders and cause a positive reaction in the market.

Our empirical analysis provides strong statistical evidence that the bid-ask bounce is a viable explanation for the price impact asymmetry for buy and sell orders for zero leverage firms. This is because before the initial loan announcement of zero leverage firms, the spread of buy orders is higher than sell orders. This is due to the fact that buy orders are motivated by both information and liquidity factors. Market makers post a higher spread according to their requirements based on both private information and liquidity. During the announcement period, the favorable firm-level news attracts more buy orders leading to the liquidity increasing, reflected by decreasing bid-ask spreads. These effects are permanent because the increasing liquidity is present in the long-term.

\section{[INSERT TABLE 5 HERE]}

\section{Conclusion}

We are the first study to analyze the price impact of buys and sells of 96 zero-leverage firms listed on the FTSE 350 index around their initial loan announcement. Our estimation process is based on a large sample with around 28 million share purchases and 26 million sell orders, over the time of period 2000 to 2015. We discover price continuations following buys and reversals succeeding sales around the initial loan announcement period. We also observe that 
purchases have a greater impact on permanent price changes, supporting the information hypothesis. Once price effects are estimated using quote returns to eliminate the bid-ask bias, the asymmetry in buyer-and seller-initiated trades is dramatically reduced. Furthermore, we report that the asymmetric information between buy and sell orders and the bid-ask bounce, is significantly greater for zero leverage firms when compared to levered firms listed on the FTSE 350 index over the same time period.

In order to measure the bid-ask bounce error caused by stock trading, we compare the quoted spreads and relative spreads of buy orders and sell orders, in the pre-announcement period, on the initial loan announcement day and the post-announcement period. The price increases and spread decreases are associated with the buy pressure. This is because the announcement of initial loan is regarded as favorable firm-level news. Our results suggest that the bid-ask bounce can explain asymmetry in the trading direction of zero-leverage firms when they encounter debt for the first time.

Given the importance of transaction costs in explaining asymmetry in buy and sell trades and the new emerging literature on zero leverage firms when they first encounter debt, we believe our study provides important findings in two very important research areas. Future research avenues could differentiate the data into different firm, trade sizes and via industry. This would reduce the sample size, but would give further interesting insights on the behavior of zero leverage firms when they enter the credit market. 


\section{References}

Alzahrani, A.A., Gregoriou, A. and Hudson, R. (2013), "Price impact of block trades in the Saudi stock market”. Journal of International Financial Markets, Institution and Money Vol.23, pp.322-341.

Anderson, H. D., Cooper, S. and Prevost, A.K. (2006), "Block trade price asymmetry and changes in depth: Evidence from the Australian stock exchange”. The Financial Review Vol.41, pp.247-271.

Aitken, M.J. and Frino, A. (1996), "Asymmetry in stock returns following block trades on the Australian stock exchange: A note”. ABACUS, Vol. 32, No.1, pp. 54-61.

Berkman, H. Brailsford, T., and Frino, A., (2005), “A note on execution costs for stock index futures: Information versus liquidity effects”, Journal of Banking and Finance, Vol.29, pp.565577.

Blume, M. and Stambaugh, R.F. (1983), "Biases in computed returns: An application to the size effect”. Journal of Financial Economics Vol.12, No.3, pp.387-404.

Brennan, M.J., Chordia, T., Subrahmanyam, A., and Tong, Q., (2012) "Sell-order liquidity and the cross-section of expected stock returns”, Journal of Financial Economics, Vol.105, pp.523541.

Brooks, R., and Chiou, S., (1995), "A bias in closing prices: The case of the when-issued pricing anomaly”, Journal of Financial and Quantitative Analysis, Vol. 30(3), pp.441-454.

Chan, L. and Lakonishok, J. (1993), "Institutional trades and intraday stock price behavior". Journal of Financial Economics. Vol.33, pp.173-199.

Chiyachantana, C., Jain, P.K., Jiang, C., and Sharma, V. (2017), "Permanent price impact asymmetry of trades with institutional constraints”. Journal of Financial Markets. Vol. 26, pp.1-16.

Cox. D.R. and Peterson. D.R. (1994), "Stock returns following large one-day declines: Evidence on short-term reversal and long term performance.” Journal of Finance. Vol. 49, pp.255-267.

Dang,V.A., (2013), "An Empirical Analys is of Zero-Leverage Firms: New Evidence from the UK”. International Review of Financial Analysis. Vol.30, pp.189-202.

Datta, S., Iskandar-Datta, M. and Patel, A., (1999), "Bank Monitoring and the Pricing of Corporate Public Debt.” Journal of Financial Economics Vol.51, pp. 435-449.

Engle, R.F., and Patton, A.J. (2004), "Impacts of trades in an error-correction model of quote prices”, Journal of Financial Markets, Vol. 7, No. 1, pp. 1-25.

Faulkender, M., and Petersen, M.A., (2005), "Does the Source of Capital Affect Capital Structure?” The Review of Financial Studies Vol.19(1), pp. 45-79. 
Frino, A., and Oetomo, T. (2005), "Slippage in future markets: Evidence from the Sydney futures exchange”, Journal of Futures Markets, Vol.25,pp.1129-1146.

Frino, SA., Bjursell, J., Wang, G.H.K., and Lepone, A., (2008),'Large trades and intraday futures price behavior”, Journal of Futures Markets, Vol28(12), pp.1147-1181.

Frino, A., Mollica, V., Romano, M.G., and Zhou, Z., (2017), “Asymmetry in the permanent price impact of block purchases and sales: Theory and empirical evidence”, Journal of Futures Markets, Vol.37(4), 359-373.

Gemmill, G. (1996), "Transparency and Liquidity: a study of block trades in the London Stock Exchange under different publication rules”. Journal of Finance, Vol.51, No.5, pp.1765-90.

Gregoriou, A. (2008), "The asymmetry of the price impact of block trades and the bid-ask spread: evidence from the London Stock Exchange”. Journal of Economic Studies. Vol.35, No.2, pp.191-199.

Gregoriou, A. (2015), "Market quality of dealer versus hybrid markets for illiquid securities: New evidence from the FTSE AIM Index”. European Journal of Finance, Vol.2(6), pp,466485.

Gosnell, T.F., Keown, A.J., and Pinkerton, J.M., (1996), "The intraday speed of stock price adjustment to major dividend changes: Bid-ask bounce and order flow imbalance”. Journal of Banking and Finance, Vol.20,pp. 247-266.

Hadlock, C.J., Pierce,J.R.,(2010), "New Evidence on Measuring Financial Constraints: Moving beyond the KZ Index”. Review of Financial Studies Vol.2(5), pp.1909-1940.

Han,Y., and Lesmond, D.,(2011), "Liquidity biases and the pricing of cross-sectional idiosyncratic volatility”. Review of Financial Studies Vol. 24(5), pp. 1590-1629.

Hasbrouck, J. and Ho, T.S. (1987), "Order arrival, quote behavior and the Return-Generating process”. Journal of Finance Vol. 42, No. 4, pp. 1035-1048.

Kaul, G. and Nimalendran, M. (1990), "Price reversals: Bid-ask errors or market overreaction?” Journal of Financial Economics, Vol. 28, pp. 67-93.

Keim, D.B. and Madhavan, A. (1996), "The upstairs market for large-block transactions: Analysis and measurement of price effects”, Review of Financial Studies, Vol. 9, pp. 1-36.

Kraus, A. and Stoll, H, (1972), "Price impacts of block trading on the New York Stock Exchange.” Journal of Finance, Vol. 27, pp. 569-588.

Lease, R., Masulis, R. and Page, J. (1991), "An investigation of market microstructure impacts on event study returns”, Journal of Finance. Vol. 46, No. 4, pp. 1523-36.

Lee, C. (1992), "Earnings News and small traders: An intraday analysis." Journal of Accounting and Economics, Vol.15 No. 2-3, pp. 265-302. 
Lee C. M.C. and Ready, M.J. (1991), "Inferring trade direction from intraday data". Journal of Finance, Vol. 46, pp. 733-746.

Levi, S., and Zhang, X., (2015), "Asymmetric decrease in liquidity trading before earnings announcements and the announcement return premium”, Journal of Financial Economics, Vol. 118, pp.383-398.

Madhavan, A. and Cheng, M. (1997), "In search of liquidity: Block trades in the upstairs and downstairs markets.” Review of Financial Studies, Vol.10, pp.175-204.

Odders-White, E., (2000), "On the occurrence and consequences of inaccurate trade classification”, Journal of Financial Markets, Vol. 3, pp.259-286.

Roll, R. (1984), "A simple implicit measure of the effective bid-ask spread in an efficient market”. Journal of Finance, Vol.39 No.4, pp.1127-1139.

Saar,G., (2001), "Price impact asymmetry of block trades: An institutional trading explanation”, Review of Financial Studies, Vol. 14,pp. 1153-1181.

Scholes, M. (1972), "The market for securities: Substitution versus price pressure and the effects of information on share prices.” Journal of Business, Vol.45, No.2, pp. 179-211.

Strebulaev, I.A., and Yang, B. (2013), "The mystery of zero-leverage firms". Journal of Financial Economics, Vol.109, pp. 1-23.

Theissen, E., (2001), "A test of the accuracy of the Lee/Ready trade classification algorithm”, Journal of International Financial Markets Institutions and Money, Vol.11 (2), pp.145-165. 


\section{Table 1. Descriptive Statistics}

Table 1 presents the summary statistics of 96 zero-leverage firms listed on the FTSE 350 that undertookan initial loan during the time period of 2000-2015. Panel A provides the descriptive statistics on borrower firms. Market capitalization is calculated as the natural logarithm of the firm's market capitalization measured by pounds. Absolute spread is defined as ask price minus bid price. Relative spread is defined as ask price minus bid price, then divided by the quoted midpoint. Effective spread is defined as two times the trade price minus the quoted midpoint. The midpoint is the ask price minus bid price divided by two. Panel B provides the disclosed amount to be borrowed by the zero-leverage firm measured in pounds. PanelC presents the purchases and sales of sample firms for the period, including the number of trades, the mean, median, minimum, maximum and standard deviation.

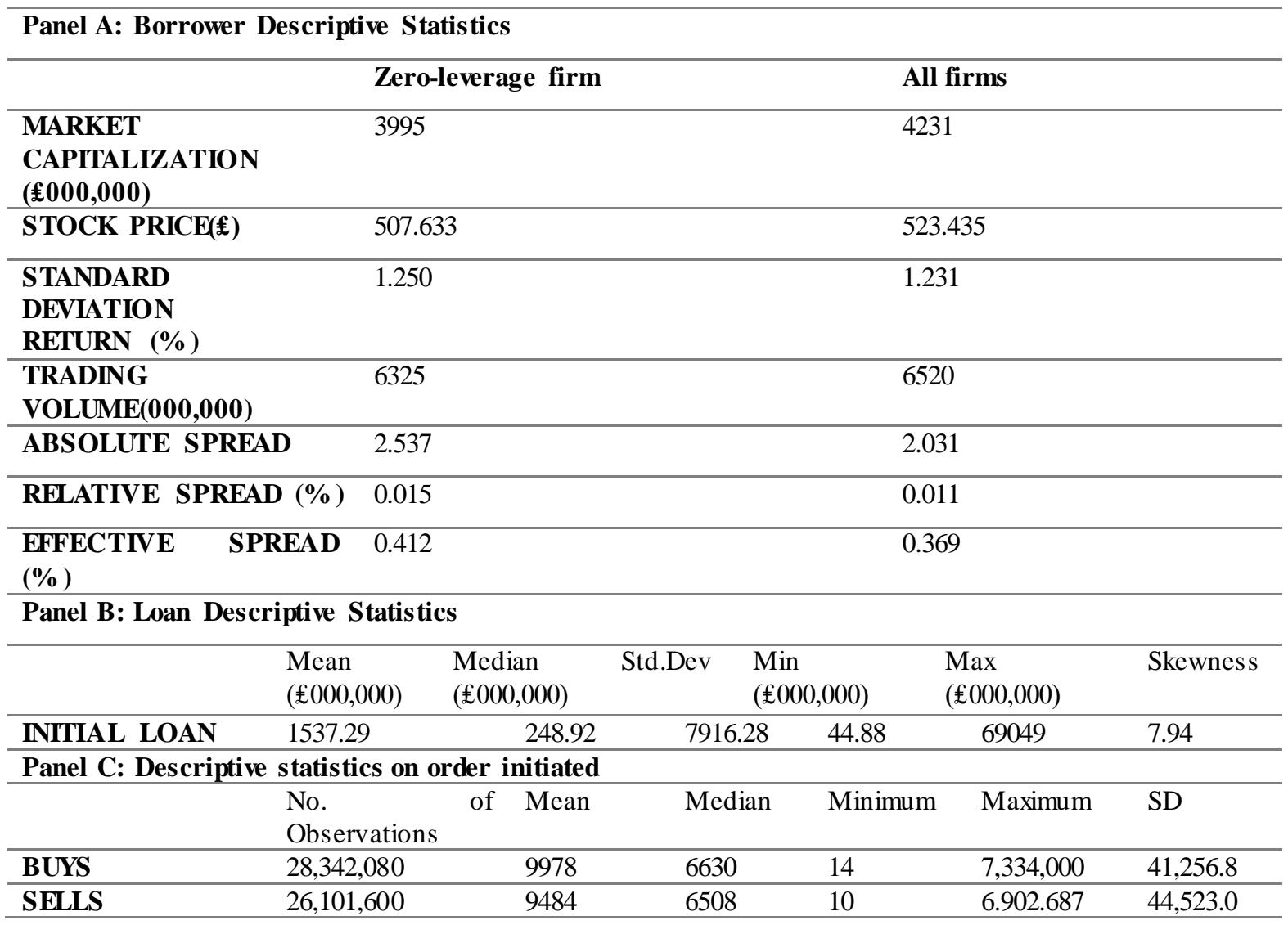




\section{Table 2. Transaction price effects of zero-leverage firm and all other FTSE 350 index firm trades}

Panel A of Table 2 reports the intraday transaction returns of 96 zero-leverage firms listed on the FTSE 350 index, trading on their initial loan announcement days for the period January 1, 2000 to December 31, 2015, broken down by buyer and seller orders. Panel B reports the average transaction returns of all other FTSE 350 index firms, broken down by buyer and seller orders during the same time period. Three measures of price impact are reported. (1) Temporary effect, defined as the logarithmic return from the closing price on the day of the initial loan announcement to the share price. (2) Permanent effects, defined as the logarithmic return from the opening price on the day of initial loan announcement to the closing price on the announcement day. (3) Total effect, defined as the logarithmic return from the opening price on the announcement day to the trading price. The tests of equality between two groups by performed using a two-sample mean comparison t-test. Standard errors are reported in parentheses, ${ }^{*}$ significance at the $10 \%$ level. ${ }^{* *}$ significance at the $5 \%$ level. ${ }^{* * *}$ significance at the $1 \%$ level.

\begin{tabular}{|c|c|c|c|}
\hline \multicolumn{4}{|c|}{ Panel A: Zero-leverage firms $(n=96)$} \\
\hline & \multicolumn{3}{|c|}{ Trade Returns } \\
\hline & Temporary & Permanent & Total \\
\hline \multicolumn{4}{|l|}{ Buy orders } \\
\hline Mean & -4.84 & 27.99 & 40.00 \\
\hline SD & 100.50 & 228.00 & 144.00 \\
\hline T-statistics & -1.33 & $26.08 * * *$ & $34.66 * * *$ \\
\hline \multicolumn{4}{|l|}{ Sell orders } \\
\hline Mean & 2.56 & -22.69 & -33.07 \\
\hline SD & 158.00 & 96.27 & 106.28 \\
\hline T-statistics & 6.26 & $-62.07 * * *$ & $-49.54 * * *$ \\
\hline \multicolumn{4}{|c|}{ Test of Equality } \\
\hline Mean & 2.28 & 5.30 & 6.93 \\
\hline T-statistics & $5.80 * * *$ & $2.96 * *$ & $2.58 * *$ \\
\hline \multicolumn{4}{|c|}{ Panel B: All other FTSE 350 index firms } \\
\hline & \multicolumn{3}{|c|}{ Trade Returns } \\
\hline & Temporary & Permanent & Total \\
\hline \multicolumn{4}{|l|}{ Buy orders } \\
\hline Mean & 3.88 & 13.47 & 18.69 \\
\hline SD & 98.40 & 79.99 & 128.05 \\
\hline T-statistics & 1.62 & $17.89 * * *$ & $20.73 * * *$ \\
\hline \multicolumn{4}{|l|}{ Sell orders } \\
\hline Mean & -2.04 & -7.82 & -14.96 \\
\hline SD & 108.26 & 138.41 & 112.99 \\
\hline T-statistics & $-4.03 * *$ & $-11.03 * * *$ & $-25.48 * * *$ \\
\hline \multicolumn{4}{|c|}{ Test of Equality } \\
\hline Mean & 1.84 & 3.65 & 3.73 \\
\hline T-statistics & $4.63 * * *$ & $3.51 * *$ & $3.44 * *$ \\
\hline
\end{tabular}




\section{Table 3. Quotes price effects of zero-leverage firm trades and all other FTSE 350 index firm trades}

Panel A of Table 3 reports the intraday quote returns purged of bid-ask bias of 96 zero-leverage firms listed on the FTSE350 index trading during their initial loan announcement day for the period January 1, 2000 to December 31, 2015, broken down by buyer and seller orders. Panel B reports the average quote returns of all other levered FTSE 350 index firms, broken down by buyer and seller orders during the same time period. Three measures of price impact are reported. (1) Temporary effect, defined as the logarithmic return from the closing price on the day of the initial loan announcement to the share price. (2) Permanent effects, defined as the logarithmic return from the opening price on the day of initial loan announcement to the closing price on the announcement day. (3) Total effect, defined as the logarithmic return from the opening price on the announcement day to the trading price. The tests of equality between two groups are performed using a two-sample mean comparison t-test. Standard errors are reported in parentheses, ${ }^{*}$ significance at the $10 \%$ level. ${ }^{* *}$ significance at the $5 \%$ level. ${ }^{* * *}$ significance at the $1 \%$ level.

\begin{tabular}{|c|c|c|c|}
\hline \multicolumn{4}{|c|}{ Panel A: Zero-leverage firms $(n=96)$} \\
\hline & Temporary & Permanent & Total \\
\hline Buy orders & \multicolumn{3}{|c|}{ Ask-Trade-Ask Returns } \\
\hline Mean & 1.38 & 20.49 & 33.76 \\
\hline SD & 99.82 & 104.33 & 155.26 \\
\hline T-statistics & $24.33 * * *$ & $26.98 * * *$ & $20.74 * * *$ \\
\hline Sell orders & \multicolumn{3}{|c|}{ Bid-Trade-Bid Returns } \\
\hline Mean & -3.26 & -16.39 & -30.28 \\
\hline SD & 150.74 & 123.55 & 213.49 \\
\hline T-statistics & $-27.83 * * *$ & $-20.65 * * *$ & $-31.22 * * *$ \\
\hline \multicolumn{4}{|c|}{ Test of Equality } \\
\hline Mean & 1.88 & $4.10 * * *$ & $3.48 * *$ \\
\hline T-statistics & $9.46^{* * *}$ & $2.48^{*}$ & $2.90^{* *}$ \\
\hline \multicolumn{4}{|c|}{ Panel B: All other FTSE 350 index firms } \\
\hline & \multicolumn{3}{|c|}{ Ask-Trade-Ask Returns } \\
\hline & Temporary & Permanent & Total \\
\hline \multicolumn{4}{|l|}{ Buy orders } \\
\hline Mean & 3.07 & 9.24 & 15.03 \\
\hline SD & 58.76 & 109.23 & 99.84 \\
\hline T-statistics & $29.47 * * *$ & $11.30 * * *$ & $14.96 * * *$ \\
\hline Sell orders & \multicolumn{3}{|c|}{ Bid-Trade-Bid Returns } \\
\hline Mean & -2.01 & -6.26 & -12.75 \\
\hline SD & 133.62 & 97.34 & 111.55 \\
\hline T-statistics & $-16.83^{* * *}$ & $-10.08 * * *$ & $-15.24 * * *$ \\
\hline \multicolumn{4}{|c|}{ Test of Equality } \\
\hline Mean & 1.06 & 2.98 & 2.28 \\
\hline T-statistics & $3.74 * *$ & $2.06 * *$ & $1.48^{*}$ \\
\hline
\end{tabular}


Table 4. Closing prices relative to bid and ask quotes surrounding the initial loan announcement date of zero-leverage firm and all other FTSE 350 index firms

Panel A of Table 4 reports that the percentage distribution of daily opening and closing prices in relation to the bid and askquotes, and order flow ratios of 96 zero-leverage firms in FTSE350 index, trading on their initial loan announcement day for the period January 1, 2000 to December 31, 2015. Panel B provides the percentage distribution of daily opening and closing prices in relation to the bid and ask quotes for all other FTSE 350 index firms. The relative frequencies across the three categories of trade positively relative to quotes in addition to order flow ratio, which is calculated as (ask price-trading price)/(ask price - bid price). We also provide chi-square tests of equality for the position of opening and closing transaction across the categories. * ${ }^{*}$ significance at the $10 \%$ level. ${ }^{* *}$ significance at the $5 \%$ level. ${ }^{* * *}$ significance at the $1 \%$ level.

\begin{tabular}{|c|c|c|c|c|}
\hline \multicolumn{5}{|c|}{ Panel A: Zero-leverage firms trading } \\
\hline Trade & At ask & At midpoint & At bid & Order flow \\
\hline \multicolumn{5}{|c|}{ Distribution of Open and Closing Prices } \\
\hline Open & $17.61 \%$ & $43.44 \%$ & $13.94 \%$ & 0.453 \\
\hline Close & $29.45 \%$ & $20.08 \%$ & $26.50 \%$ & 0.468 \\
\hline \multicolumn{5}{|c|}{ Tests of Percentages of Prices by Bid-ask Position } \\
\hline Open & Equality & & $X^{2}=233^{*}$ & \\
\hline Close & Equality & & $X^{2}=194 *$ & \\
\hline \multicolumn{5}{|c|}{ Panel B: All other FTSE 350 firms trading } \\
\hline Trade & At ask & At midpoint & At bid & Order flow \\
\hline \multicolumn{5}{|c|}{ Distribution of Open and Closing Prices } \\
\hline Open & $22.38 \%$ & $39.56 \%$ & $20.07 \%$ & 0.489 \\
\hline Close & $26.50 \%$ & $37.24 \%$ & $19.28 \%$ & 0.477 \\
\hline \multicolumn{5}{|c|}{ Tests of Percentages of Prices by Bid-ask Position } \\
\hline Open & Equality & & $X^{2}=169 *$ & \\
\hline Close & Equality & & $X^{2}=157 *$ & \\
\hline
\end{tabular}


Table 5. Bid-ask bounce of buy and sell around the initial loan announcement of zero-leverage firms and all other FTSE350 index firms

Table 5 reports the daily bid-ask bounce effect around the initial loan announcement period of 96 zero-leverage firm listed on the FTSE350 index, trading around the initial loan announcement day for the period January 1, 2000 to December 31, 2015. We also compute the average daily bid-ask bounce effect of all other FTSE 350 index firms during the same time period. Panel A comprise both daily quoted spread and relative spread in 90 days before the announcement day between buy and sell orders. Panel B and Panel C reports the day of the initial loan announcement, and 90 days after the initial loan announcement respectively. Quoted spread is defined as the ask price minus the bid price, and the average relative spread defined as the ask price minus the bid price, divided by the average of the bid and ask prices. Asymmetry shows the differences between the buy and sell orders'spread. Standard errors are reported in parentheses, ${ }^{*}$ significance at the $10 \%$ level. ${ }^{* *}$ significance at the $5 \%$ level. ${ }^{* * *}$ significance at the $1 \%$ level.

\begin{tabular}{|c|c|c|}
\hline & read & Relative Spread \\
\hline \multicolumn{3}{|c|}{ Panel A: 90 days before announcement day } \\
\hline \multicolumn{3}{|c|}{ Zero-leverage firms trading } \\
\hline Buy & 2.080 & 0.016 \\
\hline Sell & 2.076 & 0.019 \\
\hline Asymmetry & 0.004 & -0.003 \\
\hline T-statistic & $23.88 * *$ & $-7.69 * *$ \\
\hline \multicolumn{3}{|c|}{ All other FTSE350 firms trading } \\
\hline Buy & 1.919 & 0.009 \\
\hline Sell & 1.924 & 0.011 \\
\hline Asymmetry & -0.005 & -0.002 \\
\hline T-statistic & $-17.70 * * *$ & $-6.48 * *$ \\
\hline \multicolumn{3}{|c|}{ Panel B: The announcement day } \\
\hline \multicolumn{3}{|c|}{ Zero-leverage firms trading } \\
\hline Buy & 1.902 & 0.012 \\
\hline Sell & 1.983 & 0.017 \\
\hline Asymmetry & -0.081 & -0.005 \\
\hline T-statistic & $-44.30 * * *$ & $-25.67 * * *$ \\
\hline \multicolumn{3}{|c|}{ All other FTSE350 firms trading } \\
\hline Buy & 1.953 & 0.014 \\
\hline Sell & 1.956 & 0.015 \\
\hline Asymmetry & -0.003 & -0.001 \\
\hline T-statistics & $-18.56 * * *$ & $-5.35 * *$ \\
\hline \multicolumn{3}{|c|}{ Panel C: 90 days after announcement day } \\
\hline \multicolumn{3}{|c|}{ Zero-leverage firms trading } \\
\hline Buy & 2.022 & 0.019 \\
\hline Sell & 2.050 & 0.025 \\
\hline Asymmetry & -0.028 & -0.006 \\
\hline T-statistic & $-19.35 * * *$ & $-11.44 * *$ \\
\hline \multicolumn{3}{|c|}{ All other FTSE350 firms trading } \\
\hline Buy & 1.940 & 0.009 \\
\hline Sell & 1.944 & 0.011 \\
\hline Asymmetry & -0.004 & -0.002 \\
\hline T-statistic & $-11.43 * *$ & $-7.22 * *$ \\
\hline
\end{tabular}

